\title{
Media poster sebagai sarana edukasi masyarakat dalam upaya pencegahan covid-19
}

\author{
Masruroh $^{1 \star}$, Nur Hayati ${ }^{2}$ \\ ${ }^{1}$ Universitas Islam Lamongan, Indonesia, email: masruroh@unisla.ac.id \\ ${ }^{2}$ Universitas Islam Lamongan, Indonesia, email: nurhay185@gmail.com \\ *Koresponden penulis
}

\section{Info Artikel}

Diajukan: 04 Des 2020

Diterima: 05 Apr 2021

Diterbitkan: 21 Apr 2021

Keywords:

posters; education; covid-19

Kata Kunci:

poster; edukasi; covid-19

Lisensi:

cc-by-sa

\begin{abstract}
The outbreak of Covid-19 led the government to do some preventive action such as the promotion of health protocol and healthy lifestyle. Unfortunately, some people still ignoring the current importance of this preventive action. We need to educate them about the importance of this preventive action using alternative media such as posters. The purpose of this activity is to find poster's eligibility as a media to educate people of Dlanggu Village about preventive action to Covid19. There are three stages done in this activities. They are preparation, implementation, and evaluation stage. The design of poster have been successfully made in this activity with an average score of 3.5. The result showed, in general, this poster was a good media to educate people about health protocol and healthy lifestyle during covid-19 pandemics.

Abstrak

Merebaknya Covid-19 membuat pemerintah melakukan berbagai tindakan pencegahan seperti kampanye protokol kesehatan serta pola hidup bersih dan sehat. Namun,masih terdapat masyarakat yang belum menyadari pentingnya hal tersebut saat ini. Sehingga edukasi masyarakat tentang pentingnya hal tersebut perlu dilakukan melalui media alternative seperti poster. Tujuan dari kegiatan ini adalah untuk mengetahui kelayakan poster sebagai sarana dalam mengedukasi masyarakat desa Dlanggu tentang upaya pencegahan Covid-19. Kegiatan ini dilakukan melalui tiga tahap, tahap persiapan, pelaksanaan, dan evaluasi. Satu desain poster telah berhasil dibuat dengan rata-rata skor penilaian 3,5. Hasil penilaian poster menunjukkan bahwa secara umum poster yang dibuat tergolong baik untuk digunakan sebagai media dalam mengedukasi masyarakat tentang protokol kesehatan dan pola hidup bersih dan sehat selama pandemi Covid-19.
\end{abstract}

\section{PENDAHULUAN}

Akhir tahun 2019, masyarakat dunia dikejutkan dengan adanya sebuah wabah penyakit pneumonia baru yang muncul pertama kali di kota Wuhan, Propinsi Hubei, China (Supriatna, 2020). WHO menamakan penyakit yang disebabkan oleh Severe Acute Respiratory Syndrome Coronavirus-2 (SARSCoV-2) ini sebagai Coronavirus Disease (Covid-19). Penyakit ini menyerang sistem pernafasan manusia. Selain dapat ditularkan melalui droplet atau percikan yang dihasilkan oleh orang yang terinfeksi ketika berbicara, batuk, 
ataupun bersin, penyakit ini juga dapat menular melalui kontak langsung dengan benda-benda yang sudah terpapar virus SARS-CoV-2 (Zukmadani et al., 2020).

Gejala klinis penyakit ini bervariasi. Orang yang terinfeksi bisa saja mengalami keadaan tanpa gejala hingga mengalami sindrom gangguan pernafasan akut dan kegagalan fungsi organ yang berakibat fatal. Gejala yang muncul ketika terinfeksi penyakit ini umumnya seperti demam, batuk, sakit tenggorokan, sakit kepala, kelelahan, nyeri otot, dan sesak nafas (Singhal, 2020). Hal inilah yang menyebabkan penyakit ini susah untuk dibedakan dengan penyakit infeksi saluran pernafasan lainnya. Pada beberapa pasien penyakit ini dapat berkembang menjadi pneumonia, kegagalan pernapasan, dan kematian (Singhal, 2020).

Penyakit ini menyebar ke berbagai negara dalam kurun waktu yang relatif cepat. Dalam kurun waktu tiga bulan sejak pertama kali dilaporkan pada Desember 2019, penyakit ini telah menginfeksi ratusan ribu orang dari berbagai negara hingga pada tanggal 12 Maret 2020 WHO menyatakannya sebagai pandemi. Jumlah kasus terinfeksi meningkat pesat hingga per 11 Agustus 2020. telah terhitung sebanyak 20.254.685 kasus terinfeksi dari total 213 negara dan teritori (Worldometer, 2020).

Di Indonesia sendiri penyakit ini terkonfirmasi pertama kali sebanyak dua kasus pada tanggal 2 Maret 2020 (Susilo et al., 2020). Penyakit ini juga menyebar cepat di Indonesia. Telah tercatat sebanyak 127.085 kasus di Indonesia per 11 Agustus 2020 (Worldometer, 2020). Berdasarkan data dari Pemerintah Provinsi Jatim tanggal 11 Agustus 2020, sebanyak 25.917 pasien terinfeksi Covid-19, 343 orang diantaranya berasal dari Kabupaten Lamongan (Pemprov Jatim, 2020). Dilansir dari Dinas Kesehatan Lamongan, per 11 Agustus 2020 tercatat 21 orang dari Kecamatan Deket positif Covid-19 satu diantaranya adalah warga desa Dlanggu (Lamongan, 2020).

Pemerintah, baik pemerintah pusat maupun daerah sudah berkoordinasi untuk melaksanakan berbagai upaya pencegahan Covid-19. Salah satu upaya yang dilakukan pemerintah ini diantaranya dengan adanya penerapan sistem Pembatasan Sosial Berskala Besar (PSBB). Upaya edukasi masyarakat tentang protokol kesehatan juga pola hidup bersih dan sehat juga sudah masif dilakukan baik melalui media sosial, iklan televisi, dan sebagainya. Namun dalam pelaksanaannya, terutama di desa-desa penerapan protokol kesehatan dan pola hidup bersih dan sehat ini kurang maksimal. Berdasarkan hasil pengamatan, masih banyak warga yang kurang menyadari pentingnya menerapkan protokol kesehatan dan pola hidup bersih dan sehat ini. Sebagai contoh, di desa Dlanggu sendiri masih banyak warga yang beraktifitas tanpa menggunakan masker, pun masih ada yang melakukan kegiatan secara berkerumun. Berdasarkan hal tersebut maka diperlukan adanya upaya edukasi bagi masyarakat desa sebagai upaya pencegahan Covid-19. Salah satu media yang dapat digunakan untuk mengedukasi masyarakat desa adalah dengan menggunakan media poster.

Poster merupakan media gambar yang digunakan untuk memudahkan proses penyampaian informasi, saran, atau ide tertentu sehingga dapat 
merangsang keinginan orang yang melihatnya untuk melaksanakan isi pesan tersebut (Yusandika et al., 2018). Arsyad menyatakan bahwa poster merupakan salah satu bentuk media cetak yang dapat dengan mudah digunakan untuk menyampaikan informasi kepada pembaca (Zukmadani et al., 2020). Poster memiliki kelebihan diantaranya, dapat diproduksi dalam jumlah besar, dapat disebarluaskan ke pelosok wilayah terpencil, dilengkapi dengan gambar yang dapat menarik perhatian, dan dapat ditempelkan di tempat-tempat umum (Dharmastuti, S. P., Kusumawati, Y., \& Wijayanti, 2017). Salah satu kelebihan poster adalah dilengkapi dengan gambar yang menarik. Media yang menarik ini akan merangsang perhatian dari pembaca di lingkungan sasaran (Subianto et al., 2018). Sebagai tambahan, kelebihan poster dibandingkan dengan media lain diantaranya adalah poster ini termasuk media yang tahan lama, tidak memerlukan listrik, dan dapat mengakomodasi banyak orang (Putu Fani Yustisa et al., 2014). Selain kelebihan, Daryanto menyebutkan media poster juga memiliki kelemahan yaitu, sangat dipengaruhi oleh tingkat pengetahuan orang yang melihatnya, dapat menimbulkan interpretasi yang beragam, menarik bagi kalangan tertentu namun bisa jadi tidak menarik bagi kalangan lainnya, serta dapat menimbulkan kebosanan apabila terpasang terlalu lama ditempat yang sama (Dharmastuti, S. P., Kusumawati, Y., \& Wijayanti, 2017) . Kekurangan media poster yang tidak dapat menstimulir efek suara dan gerak inilah yang bagi sebagian orang menyebabkan kebosanan (Putu Fani Yustisa et al., 2014). Meskipun demikian, media poster dapat menjadi salah satu alternatif media edukasi masyarakat yang terjangkau, mudah dibuat dan praktis digunakan.

Penggunaan media poster juga dapat memberikan dampak yang positif ketika digunakan untuk tujuan edukasi. Hasil penelitian terdahulu menunjukkan adanya pengaruh yang signifikan antara pemanfaatan media poster terhadap perilaku siswa (Ulum, 2017). Penggunaan media poster juga menunjukkan adanya pengaruh positif terhadap perilaku yang diharapkan dari siswa (Istiqomah; Fitnaningsih Endang Cahyawati; Widaryati, 2018). Sebagai tambahan, penggunaan media poster juga mampu meningkatkan perilaku positif siswa (Siagian et al., 2010). Berdasarkan hal tersebut diatas tujuan dari kegiatan ini adalah untuk mengetahui penilaian media poster oleh masyarakat sebagai sarana dalam mengedukasi masyarakat desa Dlanggu sebagai upaya pencegahan Covid-19. Diharapkan dengan adanya kegiatan edukasi masyarakat melalui media poster ini dapat memberikan informasi tentang protokol kesehatan dan pola hidup bersih dan sehat kepada masyarakat desa Dlanggu sebagai upaya pencegahan Covid-19.

\section{METODE PELAKSANAAN}

Kegiatan pengabdian masyarakat ini melibatkan warga desa Dlanggu Kecamatan Deket Kabupaten Lamongan sebagai kelompok sasaran. Tahapan kegiatan ini dimulai dari tahapan persiapan, pelaksanaan, dan evaluasi kegiatan. Tahap persiapan meliputi tahapan identifikasi masalah yang diperoleh melalui hasil observasi warga sekitar yang dilanjutkan dengan persiapan pembuatan media edukasi yang berupa poster. Tahapan 
pelaksanaan meliputi pemberian media poster kepada pemerintah desa dan pemasangan poster. Tahapan evaluasi kegiatan dilakukan dengan melakukan observasi dan memberikan angket penilaian poster kepada warga desa. Tahapan evaluasi ini dilakukan dengan tujuan untuk mengetahui seberapa baik penggunaan media poster dalam mengedukasi masyarakat tentang protokol kesehatan dan pola hidup bersih dan sehat selama pandemi Covid19.

Angket yang diberikan kepada masyarakat desa berisi penilaian tentang penggunaan poster sebagai media edukasi masyarakat tentang protokol kesehatan dan pola hidup bersih dan sehat selama pandemi Covid19. Angket dibuat menggunakan modifikasi skala Likert dengan rentang skor 1 sampai 4. Angket ini diberikan kepada 17 warga desa sebagai sampel. Data respon masyarakat Desa Dlanggu tentang penilaian penggunaan media poster dihitung menggunakan rumus:

$$
\frac{\text { Skor }_{\text {didapat }}}{\text { Skor }_{\text {maksimal }}} x
$$

Skor tersebut akan diinterpretasikan berdasarkan tabel berikut:

Tabel 1. Interpretasi penilaian poster

\begin{tabular}{cc}
\hline Skor & Interpretasi \\
\hline $1,0-1,7$ & Tidak Baik \\
$1,8-2,5$ & Kurang Baik \\
$2,6-3,3$ & Cukup Baik \\
$3,4-4,0$ & Baik \\
\hline
\end{tabular}

\section{HASIL DAN PEMBAHASAN}

Dalam tahap persiapan telah dihasilkan poster yang dibuat dan dirancang menggunakan aplikasi Canva dan dicetak dalam ukuran A3. Desain poster dapat dilihat pada Gambar 1.

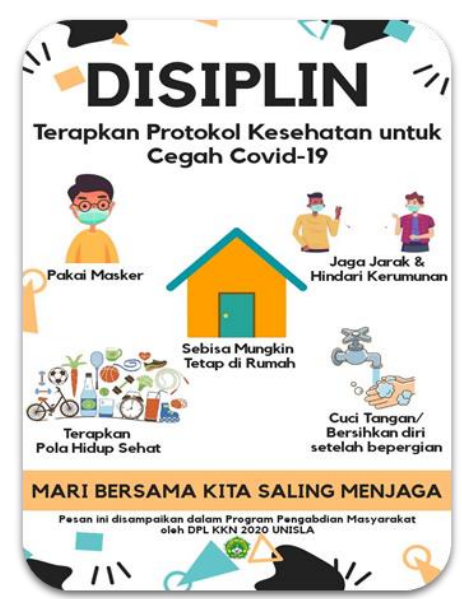

Gambar 1. Desain poster pencegahan Covid-19 
Setelah dicetak, poster diserahkan kepada perangkat desa untuk kemudian ditempelkan dibeberapa titik di desa Dlanggu. Selanjutnya, beberapa warga desa diminta untuk memberikan penilaian terhadap poster yang telah ditempelkan di beberapa titik tersebut melalui angket. Data respon warga desa dapat dilihat pada Gambar 2, 3, dan 4.

\section{TAMPILAN POSTER}

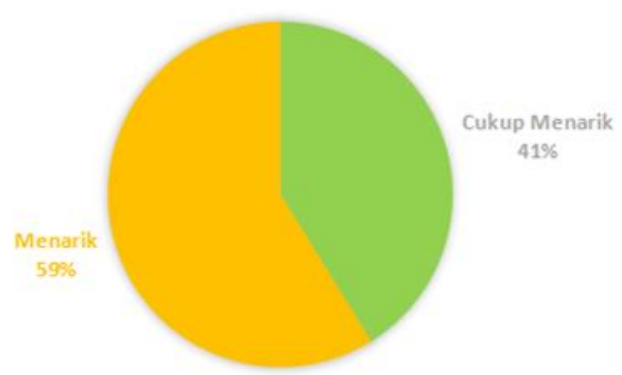

Gambar 2. Penilaian tampilan poster

Berdasarkan gambar 2, dapat diketahui bahwa sebanyak $59 \%$ warga desa menyatakan bahwa tampilan poster ini menarik, sedangkan $41 \%$ sisanya menyatakan tampilan poster ini cukup menarik. Hal ini cukup baik, mengingat salah satu tujuan dari pembuatan poster adalah untuk menyampaikan pesan dalam bentuk yang menarik. Diharapkan dengan adanya ketertarikan warga terhadap poster dapat mendorong warga desa untuk melihat lebih jauh, membaca dan memahami pesan yang disampaikan poster dengan lebih mudah. Hal ini menjadi salah satu kelebihan poster sebagai media edukasi seperti yang disampaikan oleh Effendy (Dharmastuti, S. P., Kusumawati, Y., \& Wijayanti, 2017).

\section{KEMUDAHAN UNTUK DIPAHAMI}

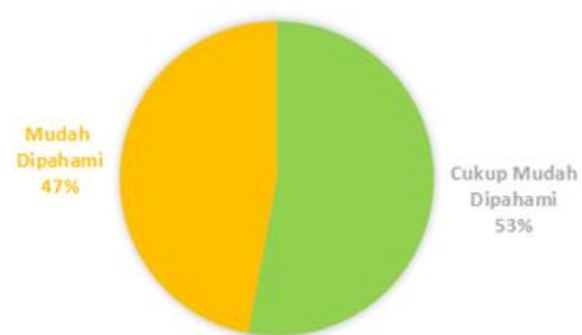

Gambar 3. Penilaian kemudahan poster untuk dipahami

Dari Gambar 3, dapat dilihat bahwa 53\% warga desa menyatakan pesan dalam poster yang dibuat cukup mudah untuk dipahami, $47 \%$ sisanya menyatakan pesan dalam poster mudah dipahami. Poster ini dibuat dengan memasukkan gambar dan kalimat penjelas yang dibuat singkat dan padat. Tujuannya agar pesan lebih mudah dipahami oleh pembaca. Hal ini sesuai 
bahwa poster merupakan media gambar yang digunakan untuk memudahkan proses penyampaian pesan (Yusandika et al., 2018).

\section{KETERBANTUAN POSTER}

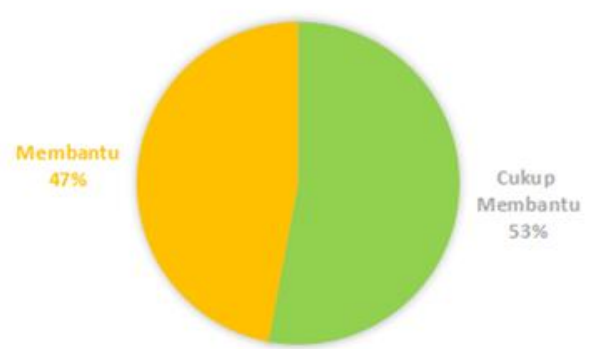

Gambar 4. Penilaian keterbantuan poster dalam edukasi

Gambar 4 menunjukkan bahwa 47\% warga desa menyatakan adanya poster ini dapat membantu dalam mengedukasi masyarakat tentang pencegahan Covid-19, sedangkan 53\% lainnya menyatakan adanya poster ini dapat membantu dalam mengedukasi masyarakat tentang pencegahan Covid19. Dengan adanya poster ini diharapkan dapat membantu mengedukasi masyarakat desa Dlanggu melalui penyampaian informasi tentang protokol kesehatan dan pola hidup bersih dan sehat selama pandemi Covid-19 sehingga nantinya dapat memberikan dampak yang positif bagi warga desa dalam upayanya untuk mencegah penyebaran Covid-19. Hal ini sejalan dengan hasil penelitian terdahulu mengenai penggunaan media poster dalam kegiatan edukasi di mana penggunaan media poster dapat memberikan dampak yang baik bagi perilaku pembaca (Istiqomah; Fitnaningsih Endang Cahyawati; Widaryati, 2018; Siagian et al., 2010; Ulum, 2017).

Hasil penilaian poster sebagai media edukasi masyarakat berdasarkan respon dari warga desa Dlanggu dapat dilihat pada Tabel 2.

Tabel 2. Penilaian poster

\begin{tabular}{cc}
\hline Aspek & Skor \\
\hline Tampilan poster & 3,6 \\
Kemudahan untuk dipahami & 3,5 \\
Keterbantuan poster & 3,5 \\
\hline Rata-rata Skor & 3,5 \\
\hline
\end{tabular}

Berdasarkan Tabel 2, dapat diketahui skor untuk aspek tampilan poster mendapatkan skor 3,6 sehingga berdasarkan Tabel 1, dapat diinterpretasikan dalam kategori baik. Sedangkan dalam aspek kemudahan pesan dalam poster untuk dipahami dan juga keterbantuan poster dalam edukasi mendapatkan skor 3,5 atau dalam kategori baik. Secara umum ratarata penilaian poster ini mendapatkan skor 3,5 sehingga dapat dikatakan poster ini sudah baik untuk digunakan sebagai media dalam mengedukasi 
masyarakat tentang protokol kesehatan dan pola hidup bersih dan sehat selama pandemi Covid-19.

\section{KESIMPULAN}

Hasil penilaian poster oleh warga desa Dlanggu menunjukkan bahwa dalam aspek tampilan poster mendapatkan kategori baik dengan skor 3,6. Dalam aspek kemudahan poster untuk dipahami dan aspek keterbantuan poster, poster ini mendapatkan kategori baik dengan skor 3,5. Dengan demikian, secara umum dapat disimpulkan bahwa poster yang dibuat sudah tergolong baik untuk digunakan sebagai media dalam mengedukasi masyarakat tentang pencegahan Covid-19 melalui penerapan protokol kesehatan serta pola hidup bersih dan sehat.

Penggunaan poster ini sebagai media dalam mengedukasi masyarakat tentunya harus dibarengi dengan kerjasama dari berbagai pihak, misalnya dari perangkat desa untuk menerapkan peraturan tentang kewajiban mematuhi protokol kesehatan di tempat-tempat fasilitas umum desa seperti balai desa, masjid, polindes, dan sebagainya. Optimalisasi kerjasama dari beberapa pihak juga sangat diharapkan dalam kegiatan edukasi masyarakat seperti kerjasama peran guru dalam mengedukasi muridnya juga peran dari masyarakat sekitar untuk secara sadar menerapkan dan saling mengingatkan tentang pentingnya protokol kesehatan dan pola hidup bersih dan sehat ini demi keberhasilan upaya pencegahan Covid-19 di desa Dlanggu.

\section{UCAPAN TERIMA KASIH}

Ucapan terimakasih disampaikan kepada LitbangPemas Universitas Islam Lamongan yang telah memfasilitasi kegiatan Pengabdian Masyarakat ini dan juga kepada Perangkat Desa dan warga desa Dlanggu Kecamatan Deket Kabupaten Lamongan atas kerjasamanya dalam pelaksanaan kegiatan Pengabdian Masyarakat ini.

\section{DAFTAR RUJUKAN}

Dharmastuti, S. P., Kusumawati, Y., \& Wijayanti, A. C. (2017). Pengaruh Pendidikan Kesehatan Tentang Bahaya Merokok Melalui Media Booklet Dan Poster Terhadap Pengetahuan Dan Sikap Siswa Smp N 2 Tasikmadu. In Doctoral dissertation, Universitas Muhammadiyah Surakarta. http://eprints.ums.ac.id/50077/1/NASKAH PUBLIKASI.pdf Istiqomah; Fitnaningsih Endang Cahyawati; Widaryati. (2018). Pengaruh Penyuluhan Mencuci Tangan Dengan Media Poster Terhadap Praktik Cuci Tangan Pada Siswa di SDN Sendangharjo Minggir Sleman [Universitas 'Aisyiyah Yogyakarta]. http://digilib2.unisayogya.ac.id/xmlui/handle/123456789/912

Lamongan, D. (2020). Covid-19 Center Lamongan - Dinas Kesehatan. https://lamongankab.go.id/dinkes/covid-19-center-lamongan/

Pemprov Jatim. (2020). JATIM Tanggap COVID-19. Republik Indonesia. http://infocovid19.jatimprov.go.id/

Putu Fani Yustisa, Aryana, I. K., \& Suyasa, I. N. G. (2014). Efektivitas 
Penggunaan Media Cetak dan Media Elektronika dalam Promosi Kesehatan Terhadap Peningkatan Pengetahuan dan Perubahan Sikap Siswa SD. Jurnal Kesehatan Lingkungan, 4(1), 29-39.

Siagian, A., Jumirah, J., \& Tampubolon, F. (2010). Media Visual Poster dan Leaflet Makanan Sehat serta Perilaku Konsumsi Makanan Jajanan Siswa Sekolah Lanjutan Atas, di Kabupaten Mandailing Natal. Kesmas: National Public Health Journal, 4(6), 262. https://doi.org/10.21109/kesmas.v4i6.165

Singhal, T. (2020). Review on COVID19 disease so far. The Indian Journal of Pediatrics, 87(April), 281-286.

Subianto, I. B., Anto, P., \& Akbar, T. (2018). Perancangan Poster sebagai Media Edukasi Peserta Didik. Jurnal Desain, 5(03), 215. https://doi.org/10.30998/jurnaldesain.v5i03.2425

Supriatna, E. (2020). Wabah Corona Virus Disease (Covid 19) Dalam Pandangan Islam. SALAM: Jurnal Sosial Dan Budaya Syar-I, 7(6), 555-564. https://doi.org/10.15408/sjsbs.v7i6.15247

Susilo, A., Rumende, C. M., Pitoyo, C. W., Santoso, W. D., Yulianti, M., Herikurniawan, H., Sinto, R., Singh, G., Nainggolan, L., Nelwan, E. J., Chen, L. K., Widhani, A., Wijaya, E., Wicaksana, B., Maksum, M., Annisa, F., Jasirwan, C. O. M., \& Yunihastuti, E. (2020). Coronavirus Disease 2019: Tinjauan Literatur Terkini. Jurnal Penyakit Dalam Indonesia, 7(1), 45-67. https://doi.org/10.7454/jpdi.v7i1.415

Ulum, A. F. (2017). Pengaruh Pemanfaatan Media Poster Terhadap Perilaku Siswa dalam Menjaga Kebersihan Lingkungan di Kelas II MI Nashrul Fajar Meteseh Tembalang Semarang Tahun Pelajaran 2016/2017 [Universitas Islam Negeri Walisongo Semarang]. http://eprints.walisongo.ac.id/8263/1/133911044.pdf

Worldometer. (2020). Coronavirus Update (Live): Cases and Deaths from COVID-19 Virus Pandemic. Worldometers. https://www.worldometers.info/coronavirus/\%0Ahttps://www.worldomet ers.info/coronavirus/?

Yusandika, A. D., Istihana, I., \& Susilawati, E. (2018). Pengembangan Media Poster sebagai Suplemen Pembelajaran Fisika Materi Tata Surya. Indonesian Journal of Science and Mathematics Education, 1(3), 187196. https://doi.org/10.24042/ijsme.v1i3.3593

Zukmadani, A. Y., Karyadi, B., \& Kasrina. (2020). Edukasi Perilaku Hidup Bersih dan Sehat (PHBS) dalam Pencegahan COVID-19 Kepada Anak-Anak di Panti Asuhan. Jurnal Pengabdian Masyarakat, 3(1), 6876. https://doi.org/10.29303/jpmpi.v3i1.440 